\title{
Public Speaking Sosialisasi Penyelenggaraan Pendidikan Keluarga Kabupaten Ngawi
}

\author{
Elisa Novie Azizah ${ }^{1}$, Destita Shari ${ }^{2}$ Intan Nur Nafiah ${ }^{3}$ \\ Program Studi Pendidikan Guru PAUD, STKIP Modern Ngawi \\ ( $\underline{\text { elisanovie3@gmail.com }}{ }^{1}, \underline{\text { destita@ unusa.ac.id }}{ }^{2}$, intannafiah20@ @mail.com $^{3}$ )
}

\begin{abstract}
ABSTRAK
Institusi keluarga memiliki peran mengajarkan nilai-nilai sebagai bekal anggota keluarga bertindak dalam kehidupan sehari-hari. Pendidikan keluarga, merupakan bagian dari pendidikan di luar sistem persekolahan (pendidikan nonformal dan informal) yang secara integral dan bersama-sama pendidikan persekolahan (pendidikan formal) memiliki peran dalam menghasilkan karakter manusia Indonesia yang sesuai dengan tujuan pendidikan nasional. Selajutnya public speaking merupakan sebuah kemahiran yang harus dimiliki oleh seorang public relations untuk menyampaikan suatu informasi penting (khususnya tentang Penyelenggaraan Pendidikan Keluarga). Namun, banyak orang yang masih merasa kurang percaya diri untuk berbicara di muka umum.

Tujuan dari Pengabdian Masyarakat ini yakni, untuk meningkatkan kemampuan public speaking peserta dalam menyampaikan materi pendidikan keluarga di wilayah Kabupaten Ngawi. Sedangkan metode yang dipakai dalam Pengabdian Masyarakat ini memakai metode diskusi, ceramah bervariasi, Pre-Test dan Post-Test. Selanjutnya ketercapaian pemahaman materi yang disampaikan dinilai cukup baik dengan meningkatnya hasil dari pre-test dan post-test yang telah dilakukan. Berdasarkan soal yang telah dibuat sebagai instrumen pengukuran pemahaman peserta, rata-rata peserta mendapatkan nilai 47,5 pada tes awal (pre-test) dan mendapatkan nilai 63,1 pada tes akhir (post-test), hal tersebut menunjukkan peningkatan pemahaman materi oleh peserta pasca pemberian materi.
\end{abstract}

Kata kunci : Public Speaking, Pendidikan Keluarga

\section{ABSTRACT}

Family institutions have the role of teaching values as provisions for acting family members in daily life. Family education, is part of education outside the schooling system (nonformal and informal education) which integrally and together schooling education (formal education) has a role in producing Indonesian human character in accordance with the objectives of national education. Furthermore, public speaking is a skill that must be possessed by a public relations to convey important information (especially about Family Education Organization). However, many people still lack the confidence to speak in public.

The purpose of this Community Service is to improve the ability of public speaking participants in delivering family education materials in the Ngawi Regency area. While the method used in Community Service uses the method of discussion, varied lectures, Pre-Test and Post-Test. Furthermore, the achievement of understanding the material presented is considered quite good with the increasing results of the pre-test and post-test that have been done. Based on the questions that have been made as an instrument to measure participants' understanding, on average the participants get a score of 47.5 in the initial test (pre-test) and get a value of 63.1 in the final test (post-test), it shows an increase in understanding of the material by participants after giving the material.

Keywords : Public Speaking, Family Education 


\section{PENDAHULUAN}

Keluarga merupakan institusi sosial yang memiliki peran penting dalam peningkatan kualitas masyarakat. Keluarga merupakan cerminan dari keadaan masyarakat, karena keluarga adalah bagian dari pembentuk karakter masyarakat. Secara umum, pembentukan keluarga memiliki tujuan yakni untuk mencapai kesejahteraan serta keluarga yang berkualitas dan berdaya. Kualitas keluarga merupakan kondisi ideal yang terdiri dari komponen edukasi, kesehatan, finansial, sosial budaya, kemandirian, mental spiritual serta nilai-nilai religi.

Pendidikan keluarga merupakan pendidikan yang pertama dan utama. Pendidikan keluarga adalah proses penyemaian pemikiran positif bagi perkembangan anak sebagai dasar pendidikan lanjutannya (Mansur, 2005). Abdullah memberikan pendapat yang menyatakan bahwa pendidikan keluarga merupakan berbagai usaha yang dilakukan oleh orangtua berupa pembiasaan dan improvisasi untuk membantu perkembangan pribadi anak (Abdullah, 2003). Pemerintah melalui Direktorat Pembinaan Pendidikan Keluarga Kementerian Pendidikan dan Kebudayaan memiliki program pendidikan keluarga dengan sasaran pemangku kebijakan pada jalur pendidikan formal, nonformal, dan informal. Alasan mengapa sasaran pendidikan bukan hanya pada ranah pendidikan informal saja, karena wujud aplikasi dari pembiasaan baik (komunikasi efektif dan komunikasi santun) pada keluarga juga harus bersinergi dengan pendidikan di masyarakat maupun di sekolah. Dengan adanya program dari
Direktorat Pembinaan Pendidikan Keluarga Kementerian Pendidikan dan Kebudayaan tersebut maka perlu adanya kegiatan Public Speaking yang mampu menunjang tercapainya kegiatan sosialisai (Biimbingan Teknis) tersebut.

Public Speaking sebenarnya bukanlah aktivitas baru yang hanya dilakukan oleh manusia- manusia pada zaman modern. Bahkan sejarah telah menunjukkan bahwa akar tradisi kegiatan Public Speaking ini telah ada sejak zaman peradaban Yunani kuno, yaitu pada tradisi politiknya. Seni berbicara di depan publik ini biasanya disebut dengan nama "retorika”, dari bahasa Yunani rhĤtorikós, yang berarti "pidato", atau "pembicara publik" yang telah dipelajari bahkan sejak dalam ilmu pengantar ilmu komunikasi. Secara singkat retorika berarti pembicaraan publik atau pidato. Tokoh-tokoh yang terkenal berbicara atau melakukan retorika adalah Gorgias, Plato, dan Aristoteles dengan model komunikasi Aristoteles yang dimilikinya.

Saat ini Public Speaking dianggap merupakan tingkatan komunikasi tertinggi dalam komunikasi, dari komunikasi intrapersonal sampai komunikasi publik, yang bisa dilakukan oleh manusia dan termasuk dalam salah satu model model komunikasi yang dipelajari sejak dulu, dan siapapun dapat melakukannya serta tidak harus berada dalam ruang lingkup politik sebagaimana pada zaman dahulu. Beberapa menyebutkan bahwa suatu komunikasi dapat disebut dengan komunikasi publik apabila jumlah audiens yang berada dalam komunikasi tersebut berjumlah lebih dari sepuluh orang. Akan tetapi pada prinsipnya 
komunikasi publik memiliki bentuk sistem komunikasi massa yang melibatkan pembicara dan audiens dalam jumlah yang banyak dan tidak dapat dipahami hanya dengan model komunikasi antar pribadi.

Selanjutnya Tujuan dari Pengabdian Masyarakat tentang Public Speaking Sosialisasi Penyelenggaraan Pendidikan Keluarga Kabupaten Ngawi yakni, untuk meningkatkan kemampuan public speaking peserta dalam menyampaikan materi pendidikan keluarga di wilayah Kabupaten Ngawi.

\section{BAHAN DAN METODE}

Kegiatan program Public Speaking Sosialisasi Penyelenggaraan pendidikan keluarga Kabupaten Ngawi ini dilaksanakan pada tanggal $2-6$ Maret 2020 mulai pukul 08.00 s/d selesai WIB bertempat di Aula Dinas Pendidikan Kabupaten Ngawi. Jumlah peserta sebanyak 71 orang yang terdiri dari perwakilan lembaga pendidikan formal dan nonformal perwakilan lembaga pendidikan formal dan nonformal (Guru, Pengelola, Kepala Sekolah PAUD) di wilayah Kabupaten Ngawi. Untuk metode yang dipakai dalam Pengabdian Masyarakat ini memakai metode ceramah bervariasi, diskusi, Pre-Test dan Post-Test. Selanjutnya ketercapaian pemahaman materi yang disampaikan dinilai cukup baik dengan meningkatnya hasil dari pre-test dan post-test yang telah dilakukan.

\section{HASIL}

Hasil pelaksanaan program pendidikan keluarga mencakup beberapa komponen yaitu:

(1) Keberhasilan Keterwakilan Peserta, (2) Ketercapaian Pemahaman Materi Program, (3)
Ketercapaian Aplikasi Program,

Ketercapaian Pelayanan Selama Program.

Untuk Keberhasilan Keterwakilan Peserta program pendidikan keluarga ini direncanakan dari satuan pendidikan jalur pendidikan formal dan nonformal. Dari total jumlah peserta yang datang merupakan perwakilan dari 2 komponen jalur pendidikan tersebut. Selanjutnya untuk ketercapaian pemahaman materi yang disampaikan dinilai cukup baik dengan meningkatnya hasil dari pre-test dan post-test yang telah dilakukan. Berdasarkan soal yang telah dibuat sebagai instrumen pengukuran pemahaman peserta, rata-rata peserta mendapatkan nilai 47,5 pada tes awal (pre-test) dan mendapatkan nilai 63,1 pada tes akhir (posttest), hal tersebut menunjukkan peningkatan pemahaman materi oleh peserta pasca pemberian materi. Untuk Ketercapaian penerapan program ini dilihat dari koordinasi yang dilakukan pada aplikasi media sosial WhatsApp Group dimana 1 minggu setelah pelaksanaan terdapat peserta yang mampu menerapkan program pendidikan keluarga di masing-masing instansinya. Sedangkan ketercapaian pelayanan kepada peserta dilihat dari angket yang disebarkan dimana rata-rata menunjukkan kepuasan atas program pendidikan keluarga yang telah dilaksanakan.

\section{PEMBAHASAN}

Pada hakikatnya, fungsi keluarga adalah sebagai pendidikan budi pekerti, sosial, kewarganegaraan, pembentukan kebiasaan dan pendidikan intelektual anak. Selanjutnya Tiga fungsi keluarga dalam pendidikan anak, yaitu (1) Fungsi kuantitatif, yaitu menyediakan bagi 
pembentukan perilaku dasar, artinya keluarga tidak hanya menyediakan kebutuhan dasar fisik anak, berupa pakaian, makanan dan minuman, serta tempat tinggal yang layak. Akan tetapi, keluarga dituntut untuk menyediakan dan memfasilitasi ketersediaan dasar-dasar kebaikan, berupa perilaku, etika, sopan santun dan pembentukan karakter anak yang santun dan berakhlak baik sebagai fitrah manusia yang hakiki, (2) fungsifungsi selektif, yaitu menyaring pengalaman anak dan ketidaksamaan posisi kemasyarakatan karena lingkungan belajar. Artinya pendidikan keluarga berfungsi sekaligus memerankan diri sebagai fungsi kontrol pengawasan terhadap diri anak akan berbagai informasi yang diterima anak. Terutama anak usia 0 tahun hingga 5 tahun yang belum memiliki pengetahuan dan pengalaman. Sehingga diharapkan mampu membedakan mana yang baik dan buruk. Oleh sebab itu, keluarga (ayah dan ibu) berkewajiban memberikan informasi dan pengalaman yang bermakna. Berupa pengalaman belajar secara langsung maupun tidak langsung, diharapkan pengalaman tersebut mampu diserap dan ditransformasi dalam diri anak, (3) Fungsi pedagogis, yaitu mewariskan nilai-nilai dan norma-norma. Artinya pendidikan keluarga berfungsi memberikan warisan nilai-nilai yang berkaitan dengan aspek kepribadian anak. Tugas akhir pendidikan keluarga tercermin dari sikap, perilaku dan kepribadian (personality) anak dalam kehidupan sehari-hari yang ditampilkan.

Pemerintah melalui Direktorat Pembinaan Pendidikan Keluarga Kementerian Pendidikan dan Kebudayaan memiliki program pendidikan keluarga dengan sasaran pemangku kebijakan pada jalur pendidikan formal, nonformal, dan informal. Alasan mengapa sasaran pendidikan bukan hanya pada ranah pendidikan informal saja, karena wujud aplikasi dari pembiasaan baik pada keluarga juga harus bersinergi dengan pendidikan di masyarakat maupun di sekolah. Dengan adanya program dari Direktorat Pembinaan Pendidikan Keluarga Kementerian Pendidikan dan Kebudayaan tersebut maka perlu adanya kegiatan Public Speaking yang mampu menunjang tercapainya kegiatan sosialisai (Biimbingan Teknis) tersebut.

Sejarah telah menunjukkan bahwa akar tradisi kegiatan Public Speaking ini telah ada sejak zaman peradaban Yunani kuno, yaitu pada tradisi politiknya. Seni berbicara di depan publik ini biasanya disebut dengan nama "retorika", dari bahasa Yunani rhĤtorikós, yang berarti "pidato", atau "pembicara publik" yang telah dipelajari bahkan sejak dalam ilmu pengantar ilmu komunikasi. Secara singkat retorika berarti pembicaraan publik atau pidato. Tokoh-tokoh yang terkenal berbicara atau melakukan retorika adalah Gorgias, Plato, dan Aristoteles dengan model komunikasi Aristoteles yang dimilikinya.

Saat ini Public Speaking dianggap merupakan tingkatan komunikasi tertinggi dalam komunikasi, dari komunikasi intrapersonal sampai komunikasi publik, yang bisa dilakukan oleh manusia dan termasuk dalam salah satu model model komunikasi yang dipelajari sejak dulu, dan siapapun dapat melakukannya serta tidak harus berada dalam ruang lingkup politik sebagaimana pada zaman dahulu. Beberapa menyebutkan bahwa suatu 
komunikasi dapat disebut dengan komunikasi publik apabila jumlah audiens yang berada dalam komunikasi tersebut berjumlah lebih dari sepuluh orang. Akan tetapi pada prinsipnya komunikasi publik memiliki bentuk sistem komunikasi massa yang melibatkan pembicara dan audiens dalam jumlah yang banyak dan tidak dapat dipahami hanya dengan model komunikasi antar pribadi.

Berikut adalah beberapa hal mengenai Public Speaking Sosialisasi Penyelenggaraan Pendidikan Keluarga Kabupaten Ngawi yang hendaknya dikuasai oleh pembicara, yakni (1) Karakteristik Public Speaking, (2) Komponen Public Speaking, (3) Teknik Vokal untuk Public Speaking, (4) Teknik Pernafasan untuk Public Speaking, (5) Persiapan, Penyampaian, Penguasaan Materi serta teknis menutup yang baik, (6) Teknik mengatasi rasa grogi

\section{KESIMPULAN DAN SARAN}

Program pengabdian kepada masyarakat ini dapat diselenggarakan secara kondusif dan memberikan kebermanfaatan kepada peserta. Meskipun terdapat beberapa catatan terkait pemahaman teori dari peserta namun dapat diatasi dengan adanya forum komunikasi yang dibuat melalui aplikasi WhatsApp Group yang dapat digunakan oleh peserta berkomunikasi dengan pemateri.

Selanjutnya Berdasarkan hasil evaluasi yang dilakukan terdapat beberapa catatan yang dapat digunakan sebagai saran pada program pendidikan keluarga selanjutnya, yakni (1) Perbaikan jadwal acara, sehingga peserta dapat menerima materi dengan baik dan menghilangkan kebosanan, (2) Pengembangan materi yang aplikatif dan sesuai dengan jalur pendidikan baik formal, nonformal, dan informal.

\section{UCAPAN TERIMA KASIH}

Kegiatan pengabdian masyarakat Bimbingan Teknis Penyelenggaraan Pendidikan Keluarga Kabupaten Ngawi ini dapat terlaksana berkat dukungan dari berbagai pihak. Oleh karena itu dalam kesempatan ini kami mengucapkan terima kasih kepada:

1. Bapak Drs. M. Taufiq Agus Susanto Selaku Kepala Dinas Pendidikan Kabupaten Ngawi

2. Bapak Istamar, M.Pd selaku Ketua Yayasan Pendidikan Modern dan Kepala Bidang PAUD Dinas Pendidikan Ngawi

3. Bapak Sarwoto, S.Pd., M.Pd selaku Ketua STKIP Modern Ngawi.

4. Ibu Arwendis Wijayanti, M.Pd selaku Ketua Program Studi PG-PAUD STKIP Modern Ngawi.

5. Serta semua pihak yang tidak dapat kami sebutkan satu persatu yang telah membantu terlaksananya kegiatan pengabdian masyarakat ini.

\section{DAFTAR PUSTAKA}

Abdullah, M. I. (2003). Pendidikan Keluarga Bagi Anak. Cirebon: Lektur.

Dunar, Hilbram. 2017. My Public Speaking. Jakarta: Gramedia.

Dunar, Hilbram. 2018. Speak for Money. Jakarta: Grasindo.

Mansur, M. (2005). Pendidikan Anak Usia Dini Dalam Islam. Yogyakarta: Pustaka Pelajar.

Purwaningsih, E. (2012). Keluarga Dalam Mewujudkan Pendidikan Nilai Sebagai Upaya Mengatasi Degradasi Nilai Moral. Jurnal Pendidikan Sosiologi dan Humaniora, 1(1). 
Rogers, Natalie. 2004. Berani Bicara di Depan Publik. Bandung:Nuansa Cendikia.

Romli, Asep Syamsul. 2008. Lincah Menulis Pandai Bicara. Bandung:Nuansa Cendikia.
Sudarsana, I. K. (2016). Peningkatan Mutu Pendidikan Luar Sekolah Dalam Upayapembangunan Sumber Daya Manusia. Jurnal Penjaminan Mutu, 1(1), 1-14.

\section{LAMPIRAN}

Grafik 1. Ketercapaian Pemahaman Materi Program

\begin{tabular}{|c|c|c|c|c|}
\hline \multicolumn{5}{|l|}{$\begin{array}{l}90 \% \\
80 \%\end{array}$} \\
\hline \multicolumn{5}{|l|}{$70 \%$} \\
\hline \multicolumn{5}{|l|}{$60 \%$} \\
\hline \multicolumn{5}{|l|}{$50 \%$} \\
\hline \multicolumn{5}{|l|}{$40 \%$} \\
\hline \multicolumn{5}{|l|}{$30 \%$} \\
\hline \multicolumn{5}{|l|}{$20 \%$} \\
\hline $10 \%$ & & & & \\
\hline $0 \%$ & Penguasaan Materi & $\begin{array}{c}\text { Memberikan } \\
\text { Materi Secara } \\
\text { Sistematis dan } \\
\text { Mudah Dipahami } \\
\end{array}$ & $\begin{array}{c}\text { Memberikan } \\
\text { Contoh Yang } \\
\text { Menarik dan } \\
\text { Mudah Diingat }\end{array}$ & $\begin{array}{c}\text { Mendorong } \\
\text { Peserta Ikut Aktif } \\
\text { Dalam Kelas }\end{array}$ \\
\hline DKurang & $0 \%$ & $0 \%$ & $0 \%$ & $3 \%$ \\
\hline gCukup & $8 \%$ & $5 \%$ & $5 \%$ & $3 \%$ \\
\hline Daik & $70 \%$ & $78 \%$ & $78 \%$ & $65 \%$ \\
\hline$\square$ Sangat Baik & $23 \%$ & $18 \%$ & $18 \%$ & $33 \%$ \\
\hline
\end{tabular}

Grafik 2. Ketercapaian Pelayanan Selama Program

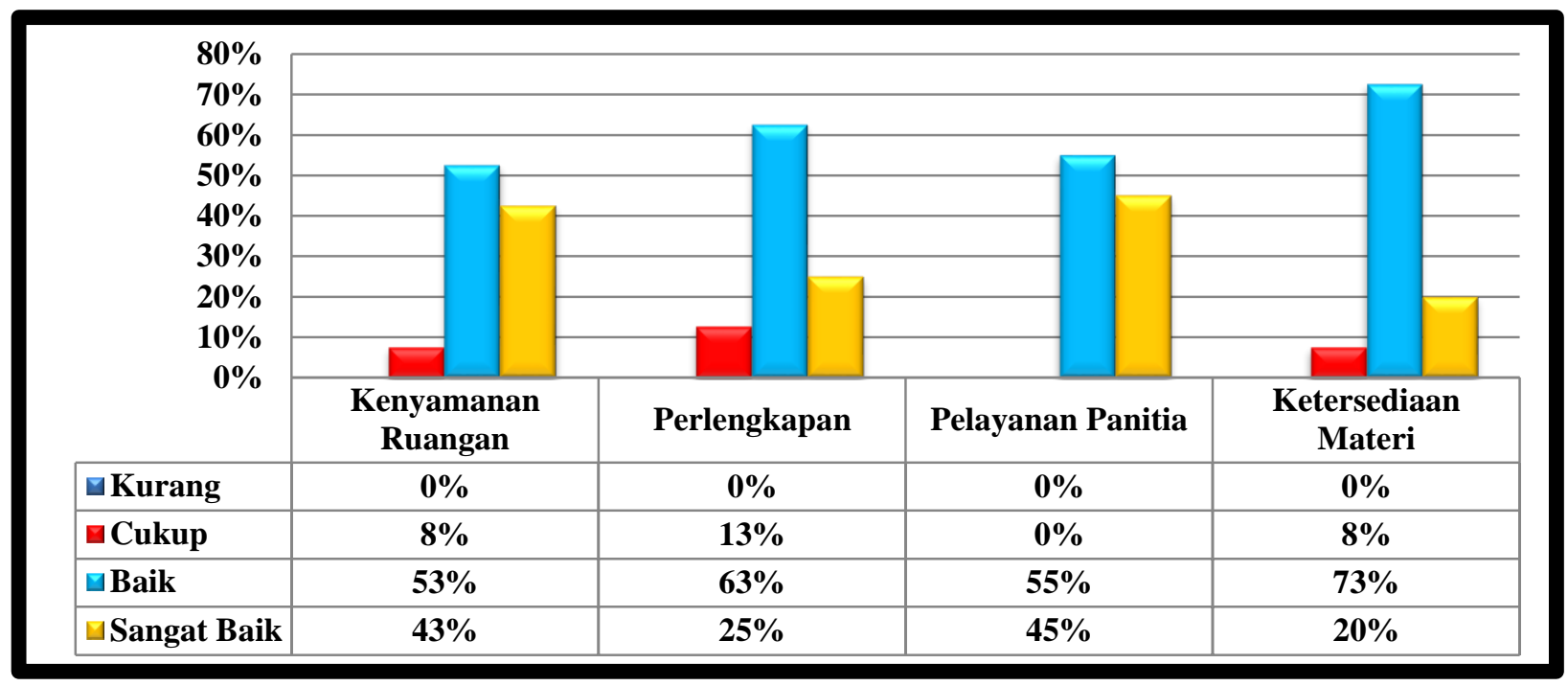

